\title{
PATRA PINDA SWEDANA (A Unique Method of Massage with Fomentation) : A Review
}

\author{
Dr. Achala R. Kumawat; Dr. Gopesh Mangal
}

\begin{abstract}
Swedana or Fomentation is a treatment practice which induces sweating by means of heat either in the form of steam (Bashpa) or by direct contact of the body with heated medicament (Tapa).Sankara Sweda, commonly known asPinda Swedais a fomentation method in which the materials are tied in a cloth and massaged over the part to be sudated.In PatraPindaSweda, a type of Pinda Sweda, different medicinal leaves along with other drugs are roasted in suitable medicated oil, made intoPinda(bolus) form by tying them in a suitable cloth and used for Swedanaafterperforming Abhyanga (mild massage). Swedana, in generally relieves pain, stiffness, heaviness, and coldness in the body. This treatment procedure eliminates the bodily toxins through sweating.It provides better therapeutic efficacy in orthopedic disorders especially in diseases like Osteoarthritis, Rheumatoid Arthritis, Cervical spondylosis, Lumbar spondylosis,Ankylosing Spondylitis, musculoskeletal pain as well as in neuro-muscular diseases. Present article deals with literary as well as contemporary review of the Patra Pinda Swedana.
\end{abstract}

Keywords:- Fomentation, Patra Pinda Swedana, Sankara Sweda, Tapa Sweda.

\section{INTRODUCTION}

The term PatraPinda Swedana is derived from the words Patra,(meaning leaves), Pinda which means bolus, and Swedana, which means sweating. So, PatraPindaSwedana refers to the sudation performed by a specially prepared bolus of medicinal leaves (generally Vatakaphahara).

\section{MATERIALS \& METHODS}

References regarding Swedana and Patra Pinda Swedana were collected from various textbooks, published research papers, previous work done and compilation was done. Conceptof Patra Pinda Swedana and procedure were studied in detail.

\section{LITERARY REVIEW}

Acharya Charaka has classified Swedana based on the involvement of Agni (fire)- Sagni Swedanaand Niragni Swedana ${ }^{l}$. Whereas, Acharya Sushruta and Acharya Vagbhata have classified Swedana procedure into four types mainly, Tapa (inducing sweating by direct contact of the heated medicaments with body), Ushma or Bashpa (heat in the form of steam), Drava (inducing heat by means of hot liquid), Upnaha (inducing heat by tying poultice around part to be sudated $)^{2}$. On reviewing the above classifications, it can be seen that all the 13 types of Sagni Sweda of Acharya Charaka can be incorporated into 4 types of Sweda described by Acharya Sushruta and Vagbhata.

Patra Pinda sweda is a form of Pinda sweda, which is nothing but Sankara Sweda of Acharya Charaka. ${ }^{3}$ It is a form of Tapa sweda, as per Acharya Sushruta and Acharya Vagbhata. It includes fomentation using bolus (Pinda) of prescribed drugs with or without being wrapped in cloth. ${ }^{4}$ Swedana can further be classified into Ruksha Pinda Sweda and Snigdha Pinda Sweda. In Ruksha Pinda Sweda, hot solid substances such as sand, brick and stone are used. It is indicated in Kapha and Amarelated disorders affecting joints and muscles, whereasSnigdha Sweda is advised in conditions where the pain and related symptoms are due to Vata Dosha only. Patra Pinda Sweda is a form of SnigdhaSweda and is an unparalleled treatment in painful conditions caused mainly by Vata Dosha, usually in degenerative diseases. Moreover, it can be used in VataKapha conditions also, by alteringthe drugs (leaves etc.) used. Leaves which can pacify morbid Vata and Kapha are used in the bolus for tackling inflammatory diseases of joints and soft tissues. Patra Pinda Sweda is used mainly to relief from pain, inflammation, swelling and stiffness associated with bone, joint and or musculoskeletal pains.It is generally indicated in the ailments arising due to Vata, Kapha and VatakaphaDosha.

Indications: As, it is a form of Swedana, it is generally indicated in Vatakapha Vikara. ${ }^{5}$ It can be indicated in the following ailments- Gridhrasi ( Sciatica), Sandhivata ( Osteoarthritis), Jeerna or PravruddhaAmavata ( Chronic stages of RA), Pakshavadha ( Hemiplegia), Greevastambha ( Cervical spondylosis), Katiprishthagraha ( Ankylosing Spondylitis), Avabahuka( Frozen Shoulder), Intervertebral disc protrusion or prolapse (IVDP).

Contraindications: PatrapindaSwedana is contraindicated inAjeerna( Indigestion), Jwara ( Fever), Twak Vikara ( infective eczema, Psoriasis), Raktapitta ( Hemorrhagic disorders)., Atisara ( Diarrhoea), Trishna ( Excessive thirst), Madhumeha ( Diabetes mellitus), Pandu ( Anemia), Garbhini ( Pregnant women). 


\section{PATRA PINDA SWEDANA PROCEDURE}

Every procedure of Panchakarma is carried out in three steps Poorvakarma, Pradhankarma and Paschatkarma.

Poorvakarma: Poorvakarma are the Karma that are required to be done prior to administration of Patra Pinda Swedana. They include- (a) Preparation of materials, (b)Preparation of Patient.

1. Preparation of materials and Pottali (Boluses)-

$>$ Leaves - Nirgundi(Vitex negundo),Eranda(Ricinus communis), Arka (Calatropis procera), Dhatura(Datura metel), Shigru(Moringa oliefera) etc. (chopped into pieces- 100gm each).

$>$ Sliced lemon- 2

$>$ Grated coconut- 100 gm

$>$ SaindhavaLavana- 5-10 gm.

> Haridra Churna (Curcuma longa)-10gm

$>$ Ajmoda(carum roxburghianum)- $10 \mathrm{gm}$

$>$ Oil-

- For frying leaves- $100 \mathrm{ml}$.

- For heating Pottali- $250 \mathrm{ml}$.

- For Abhyanga- $100 \mathrm{ml}$.

- For Talam-10ml

$>$ Rasnaadi Choona -5 gm for Talam

$>$ Cotton cloth $(45 \mathrm{~cm} \times 45 \mathrm{~cm}): 4$ pieces

$>$ Tags- 4

$>$ Vessels- 2 (for frying Leaves and for heating Pottali).

$>$ Attendant- 2

$>$ Panchakarma Droni-1

$>$ Gas stove-1

\section{* Preparation of Boluses:}

Fresh leaves should be cleaned and chopped finely. First add $100 \mathrm{ml}$ of prescribed oil into pan, to this add grated coconut and sliced lemon and fry till in turn to light tinged brown.Add chopped leaves one by one; first add drugs which have thick leaves followed by thin.Then mix thoroughly and fry together till coconut scrapings attain a brown color.It should be divided into two equal parts and made into 2 Pottali (average weight of a standard Pottali is 300-350 gm.).

\section{Preparation of patient.}

- Patient is advised to properly evacuate faeces and urine, prior to the procedure and to expose the area desired for Swedana.

- The patient should be seated with leg extended over the Droni facing to the east. Abhyanga should be performed with prescribed medicated oil all over the body for about 10 minutes. Talam with suitable oil/Choornashould be applied. Rasnadi Choorna is mixed with quantity sufficient oil to make a paste of coin shape. It is then applied over the anterior fontanelle of patient. Talam is applied to prevent the brain from undue effects of sudation.

\section{PRADHANA KARMA (METHOD OF ADMINISTRATION)}

The prepared Pottali should be heated with prescribed oil in a vessel on gas stove up to $42-46^{\circ} \mathrm{C}$.

The therapists before applying the boluses on the body of the patient should ensure that the heat of the boluses is bearable to the patient by checking temperature of the bolusesover dorsum of their own hand.The Patra Pottali is gently rubbed with mild pressure over the part to be sudated in a synchronized manner by two therapists positioned on each side of the patient. The fomentation by Patra Pottali should be carried out in all the 7 postures asAbhyanga ( Massage) to ensure that all thebody partsare equally fomented. The procedure of Patra Pottali Sweda should be done till the patient gets of the Samyak Swinna Lakshana ${ }^{6}$

- The treatment procedure is carried out for 5-10 minutes in each posture.

- Care should be taken to maintain the temperature throughout the procedure by reheating the Pottali.

- The leaves bolus (Pottali) should be changed in every three days

Duration: Time duration of the treatment ranges from 3045 minutes. The therapy should be done once every day for 1 to 3 weeks depending on the severity/intensity of the disease.

\section{Paschatkarma:}

After completion of the procedure, Talamis removed followed by rubbing ofRasnadiChoorna over anterior fontanelle. Oil is wiped off from the body using clean dry towel.Body is covered with thin blanket for 10-15 minutes. Patient should be advised to take hot water bath after 1Muhurta (48 minutes) ${ }^{7}$.Patient is advised to take light diet and drink hot water after procedure.

Complications and management:

a) Atiyoga of Swedana- Acharya Charka has advised use of Madhura, Snigdha, and Sheeta Ahara- Vihara as described in Greeshm Ritucharya ${ }^{8}$. He further states that Stambhana should be done in case of Atiyoga of Swedana9.

b) Burn and rashes-Due to heat intolerance in patient of Pitta Prakriti, Burn and rashes may occur which has to be managed byapplyingMadhu and Ghrita, preferably ShahstradhoutaGhrita ${ }^{10}$, GhritaKumari (Aloevera pulp $)^{11}$, Haridra with Ghrita over the affected part.

c) Fainting- Due to increased body temperature or low heat threshold of the patient or Atiyoga of Karma, fainting may occur. Fainting and Giddiness can be prevented by providing Sharkarodaka to the patient for drinking. ApplyTalam with appropriate medicated oil and Choorna. Drakshadi Kashaya can be given internally. ${ }^{12}$ 


\section{DISCUSSION}

Patra Pinda Swedana is usually done with Nirgundi Patra, Dhatura Patra, Shigru Patra, Erandapatra etc. Leaves of the Nirgundi plant have analgesic, anti-bacterial and anti-inflammatory properties. It also possesses antihistaminic properties and is muscle relaxant ${ }^{13}$. Dhatura leaves have anti-inflammatory properties and vapors of its leaves also relieve the pain of rheumatism and gout $^{14}$. Leaves of Shigru are known to reduce severe pain ${ }^{15}$. Leaves ofEranda are used to pacifyVataDosha ${ }^{16}$.

Patra Pinda Swedana is generally indicated in Vata Kaphaja conditions, owing to the properties of ingredients used. Gridhrasi and Greevastambha are Vata Kaphaja Pradhana diseases.Patra Pinda is useful in Sandhivata and Jeerna Aamavata, as these conditions are Vata Pradhana and Patra Pinda Swedana being a Snigdha sweda pacifies morbidVata. Ankylosing Spondylitis that can be considered as Kati-Prishta-Trika Graha in Ayurvedic parlance is an inflammatory arthritis that involves vitiation of Vata and Kapha, producing pain and stiffness in the spines. Nirgundi Patra Pinda Swedana owing tothe anti-inflammatory action, Snigdha and Ushna Guna of the materials used subsides the inflammation, pacifies morbid Vata and KaphaDosha thus reducing pain and stiffness. Similarly, it is effective in conditions like Avabahuka that involves vitiation of Vata and Kapha again and presents with reduced range of motion at shoulder Joint. Nirgundi Patra Pinda relieves stiffness in such cases which in turn improves the range of motion.Swedana is contraindicated in conditions of Ajeerna, as it is a Snigdha Sweda which may further increase Agnimandya. Agni is hampered in Jwaravastha, and Patrapinda Swedana may aggravate the condition in these cases.Infective eczema and Psoriasis are also a contraindication forSwedana, as it may further aggravate the conditions. Swedana is strictly contraindicated in Atisara as Swedana may increase the peristaltic movements resulting in aggravation of the condition. Moreover, it may result in electrolyte imbalance due to increased fluid loss. Acharya are of opinion that Swedana should be strictly avoided in Raktapitta even if it involves vitiation of Vata and Kapha. ${ }^{17}$ Madhumeha is a Kleda pradhana Vyadhi and Swedana increases Kleda thus Patra PindaSwedana should be avoided in such cases. Swedana aggravates Trishna and $P a n d u$, therefore should not be performed in these conditions.

Reduction of pain can be explained on the bases of gate control theory of pain of Melzak and Wall, 1965. Their theory states that different man oeuvres of massage impart an array of sensory experiences by stimulating the peripheral sensory receptors, mainly touch and pressure receptors, present in skin and soft tissue. Patra Pinda Sweda involves massage of the area with certain amount of pressure in a synchronized manner. As per Melzack and Wall, these pressure and temperature sensations are carried by large diameter Abetafibers, which plays an important role in inhibition of the perception of pain, carried by A delta and $\mathrm{C}$ fibers.The stimulation of low threshold mechanoreceptors blocks the pathway of pain sensation by presynaptic inhibition at the level of substantia gelatinosa of spinal cord. This could be the mechanism by which Patra Pinda Swedana reduces pain and stiffness.

\section{CONCLUSION}

Present article deals with comprehensive study of Patra Pinda Swedana. As discussed above it is a type of Sankar Swedaand TapaSweda. It is effective in Vata Kaphaja and Inflammatory conditions. It is most often recommended in condition like chronic back pain, arthritis, stiffness of the joints and even muscle ache. Patra Pinda Sweda may help in increasing blood circulation to the affected area, gets rid of vitiated Dosha, strengthens the muscles in the area, facilitates release of toxins and reduces inflammation. It also improves the tone of muscles and improves the working of tissues within the body.

\section{REFERENCES}

[1]. Charaka, Charaka Samhita, Sutra Sthana, Swedoadhyay, 14/65, edited by Pandit Rajeswaradatta Shastri, Chaukhambha Bharati Academy, Varanasi,2013; PP.299.

[2]. Sushruta, Sushruta Samhita, Chikitsha Sthana, Swedavacharniyachikitsha adhyay, 32/12, edited by Kaviraja Ambikadutta Shastri, Chaukhambha Sanskrit Sansthan, Varanasi,2015; PP.174.

[3]. Charaka, Charaka Samhita, Sutra Sthana, Swedoadhyay, 14/41, edited by Pandit Rajeswaradatta Shastri, Chaukhambha Bharati Academy, Varanasi,2013; PP.290.

[4]. Charaka, Charaka Samhita, Sutra Sthana, Swedoadhyay, 14/41, edited by Pandit Rajeswaradatta Shastri, Chaukhambha Bharati Academy, Varanasi,2013; PP.290.

[5]. Charaka, Charaka Samhita, Sutra Sthana, Swedoadhyay, 14/3, edited by Pandit Rajeswaradatta Shastri, Chaukhambha Bharati Academy, Varanasi,2013; PP.281.

[6]. Charaka, Charaka Samhita, Sutra Sthana, Swedoadhyay, 14/13, edited by Pandit Rajeswaradatta Shastri, Chaukhambha Bharati Academy, Varanasi,2013; PP.283.

[7]. Charaka, Charaka Samhita, Sutra Sthana, Swedoadhyay, 14/45, edited by Pandit Rajeswaradatta Shastri, Chaukhambha Bharati Academy, Varanasi,2013; PP.294.

[8]. Charaka, Charaka Samhita, Sutra Sthana, Swedoadhyay, 14/15, edited by Pandit Rajeswaradatta Shastri, Chaukhambha Bharati Academy, Varanasi,2013; PP.294.

[9]. Vagbhata, Astanga Hridaya, Sutra Stana, Swedvidhiadhyay, 17/16-17, edited by Dr. Brahmanand Tripathi, Chaukhambha Sanskrit Pratishthan, Delhi,2017; PP.216.

[10]. Charaka, Charaka Samhita, Chikitsha Sthana, Jwarachikitsha Adhyay, 3/257, edited by Dr. Gangasahaya Pandeya, Chaukhambha Sanskrit Sansthan, Varanasi; PP.123. 
[11]. Bhavamishra, Bhavaprakasa Nighantu, Guduchyaadivarga Adhyay, Verse Number 101, edited by Late Dr. G. S. Pandey, Chaukhambha Bharati Academy, Varanasi,2013; PP.404.

[12]. Sharangdhara, Sharangghara Samhita, Madhyama Khanda, Kwatha Kalpana Adhyay, 2/17, edited by Dr. Smt. Shailaja Srivastava, Chaukhambha Orientalalia, Varansi,2016; PP.138.

[13]. https://www.planetayurveda.com/library/nirgundivitex-negundo/

[14]. Soni, P., Siddiqui, A. A., Dwivedi, J., \& Soni, V. (2012). Pharmacological properties of Datura stramonium L. as a potential medicinal tree: an overview. Asian Pacific journal of tropical biomedicine, 2(12), 1002-1008. doi:10.1016/S22211691(13)60014-3. Available from:https://www.ncbi.nlm.nih.gov/pmc/articles/PM C3621465/ Last accessed on 17 June 2019.

[15]. Bhavamishra, Bhavaprakasa Nighantu, Guduchyaadivarga Adhyay, Verse Number 101, edited by Late Dr. G. S. Pandey, Chaukhambha Bharati Academy, Varanasi,2015; PP.324.

[16]. Bhavamishra, Bhavaprakasa Nighantu, Guduchyaadivarga Adhyay, Verse Number 64-66, edited by Late Dr. G. S. Pandey, Chaukhambha Bharati Academy, Varanasi,2015; PP.286.

[17]. Chakrapaani, Charaka, Charaka Samhita, Sutra Sthana, Swedoadhyay, 14/16-19, edited by Vd. Harish Chandra Singh Kushwaha, Chaukhambha Orientalalia, Varanasi,2016; PP.223. 